\title{
The knowledge economy in China and public-private partnerships of universities**
}

\author{
Maria Kaneva ${ }^{\mathrm{a}, *}$, Galina Untura ${ }^{\mathrm{b}}$ \\ ${ }^{a}$ Institute of Economics and Industrial Engineering, Siberian Branch of the Russian Academy of Sciences, Novosibirsk, \\ Russia, mkaneva@gmail.com \\ ${ }^{\mathrm{I}}$ Institute of Economics and Industrial Engineering, Siberian Branch of the Russian Academy of Sciences, Novosibirsk, \\ Russia; Novosibirsk State University, Novosibirsk, Russia, galina.untura@gmail.com
}

\begin{abstract}
A B S T R A C T
Since 1995 China officially adopted the Strategy of Revitalizing China through Science and Education to advance towards the knowledge economy. Our paper aims to access China's progress using international indices of economic and innovation development (Knowledge Economy Index, Global Competitiveness Index, and Human Development Index). We also explore six types of public-private partnerships in innovation activities of the Chinese universities. They are: technology contracts, technology transfer, university-owned enterprises, joint research centers, independent colleges, and university-based science parks. For each partnership we study the role it played in intensification of research and education with an emphasis on government participation mechanisms. Based on the analysis of the official statistics the authors find that the progress of China to the knowledge economy is evident. China's government played a leading role in the construction of the knowledge economy providing legislation basis and financing. Public-private partnerships in innovation activities in the universities in China significantly contributed to the technological development of the country and the country's transition towards the knowledge economy. Studying successful experience of the public privatepartnerships in the Chinese universities is a first step to possible adaptation of this mechanism in other countries, including Russia.
\end{abstract}

\author{
A R T I C L E I N F O \\ Keywords: \\ knowledge economy, university, \\ public-private partnership, $R \& D$, \\ China \\ *Corresponding author: \\ mkaneva@gmail.com \\ (Maria Kaneva) \\ Article Submitted 16-01-2014 \\ Article Accepted 25-02-2014 \\ **Article previously published in \\ EJEM 2014, vol 1, No. 1
}

\section{INTRODUCTION}

The knowledge (or knowledge-based) economy was first defined by OECD in 1996 as an 'economy which is directly based on the production, distribution and use of knowledge and information' (OECD, 1996, p. 7). According to the World Bank the four pillars that are critical for a country to be able to fully participate in the knowledge economy are: 1) economic incentive and institutional regime; 2) educated and skilled workforce; 3) effective innovation system; and 4) modern and adequate information infrastructure (Chen and Dahlman, 2005) ${ }^{1}$. Indeed, an educated and trained population is needed to create and share the knowledge while

\footnotetext{
${ }^{1}$ Lately many researchers consider health care to be one of the pillars of the knowledge economy.
} 
ICT is required to facilitate the communication. The growth of knowledge is most rapid when institutional conditions are favorable and innovation systems are in place.

One of the countries that made a significant progress towards the knowledge economy in the past twenty years is China. In 1995 during the all-China conference on science and technology a Strategy of Revitalizing China Though Science and Education was announced and transfer from 'Made in China' model to 'Made and created in China' model (Bai, 2011) began. Among the pillars of the knowledge economy education was chosen to act a main driver of innovation changes (Li, 2003). Reforms of the education sector assumed enhancement of the quality of educational programs; compliance of the programs with international standards, and development of universities as innovation and R\&D centers.

The success of the government-backed reforms improved the country's position in the international rankings that directly measure or include the knowledge economy component. In 2012 China was ranked no. 84 (score 4.37) in the Knowledge Economy Index of the World Bank as opposed to its rank no. 100 (score 3.99) seventeen years earlier, in 1995 (Knowledge economy index, 2012). It also rose up 15 places in the Global Competitiveness Index of the World Economic Forum since 2003 (the first year GCI based on a new methodology was calculated for) and in 2012-2013 was ranked no. 29 among 144 countries (Schwab, 2012). In the Human Development Index of the United Nations Development program China's position improved from rank 111 in 1995 (out of 174, HDI=0.594) to rank 101 in 2012 (out of 186, HDI=0.699) (Human Development Report, 2013). The overall position of China below top 100 is due to the fact that despite significant progress the education coverage with 7.5 mean years of schooling remains below the worldwide average. Nevertheless, the improvement in education level has been evident.

The Strategy of Revitalizing China through Science and Education assumed that the country will re-orient from adopting foreign technologies to producing its own. Chinese universities, universities' R\&D and innovation activities were to play a major role in the transition. In particular, the government encouraged development of public-partnerships (PPPs) in innovation sphere of educational organizations with a set of objectives linked to the accelerated transfer to the knowledge economy. These were: enhancement of the quality of research; intensification of R\&D and training; and development of close ties between universities and industry. The aim of paper is to study the effect of the public-private partnerships in innovation 
activities of the universities on China's progress towards the knowledge economy with an emphasis on mechanisms of government participation.

The research is part of a broader research program 'Economics and Sociology of Science and Education' carried out at the Institute of Economics and Industrial Engineering of the Russian Academy of Sciences. The focus of the research program is on the role of different institutions (universities, research institutes, the Russian Academy of Sciences, public-private partnerships) in the development of science and technology in different countries. Successful functioning of public-private partnerships in the innovation activities of the Chinese universities stimulated the authors to study PPPs in more detail to further consider adaptation of the PPP mechanism in the Russian universities.

In section 2 we present literature review on the topic. In section 3 we describe the methodology chosen to address the research topic and three empirical questions. Section 4 presents the results and discussion. Section 5 concludes.

Table 2: Types of public-private partnerships in innovation activities of higher education institutions in China and objectives pursued by the government

\begin{tabular}{|c|c|c|}
\hline $\begin{array}{l}\text { Type of public-private } \\
\text { partnership }\end{array}$ & Description & Goals/objectives pursued by the government \\
\hline \multirow[t]{2}{*}{$\begin{array}{l}\text { Technology contracts } \\
\text { (TCs) }\end{array}$} & $\begin{array}{l}\text { TC type 1: technology } \\
\text { development } \\
\text { Joint research: firm sets } \\
\text { research task and together } \\
\text { with university employees } \\
\text { finds solution } \\
\end{array}$ & \multirow[t]{2}{*}{$\begin{array}{l}\text {-partial financing of universities by private } \\
\text { companies } \\
\text {-development of applied science in universities } \\
\text { and close ties between science and industry } \\
\text {-creation of new jobs for university graduates } \\
\text {-transfer of tacit knowledge from science to } \\
\text { industry }\end{array}$} \\
\hline & $\begin{array}{l}\text { TC type 2\&3: technical } \\
\text { services and technical } \\
\text { consultancy } \\
\text { Provision of information } \\
\text { about different technologies } \\
\text { and organization of training in } \\
\text { different technical disciplines }\end{array}$ & \\
\hline \multirow{3}{*}{$\begin{array}{l}\text { Technology transfer and } \\
\text { licensing (TT) }\end{array}$} & TT type 1: transfer of patents & \multirow{3}{*}{$\begin{array}{l}\text { Transition from 'Made in China' to 'Made and } \\
\text { created in China' strategy via: } \\
\text { 1) development of universities as major } \\
\text { research centers } \\
\text { 2) enhancement of China's reputation at the } \\
\text { international scientific arena (through } \\
\text { increase of patenting activity). }\end{array}$} \\
\hline & TT type 2: patent licensing & \\
\hline & $\begin{array}{l}\text { TT type 3: non-patent } \\
\text { technology transfer }\end{array}$ & \\
\hline
\end{tabular}




\begin{tabular}{|c|c|c|}
\hline $\begin{array}{l}\text { University-owned } \\
\text { enterprises }\end{array}$ & $\begin{array}{l}\text { Enterprises-1. Universities' } \\
\text { factories and print shops that } \\
\text { existed in the 1980s } \\
\text { Enterprises-2. Joint ventures } \\
\text { between universities and } \\
\text { private companies } \\
\text { Enterprises-3. Firms founded } \\
\text { by university departments for } \\
\text { development of special } \\
\text { technologies } \\
\text { Main reason for establishment } \\
\text { of university-owned } \\
\text { enterprises was decrease in } \\
\text { government financing of } \\
\text { universities in the 1980s }\end{array}$ & $\begin{array}{l}\text { From } 1991 \text { to } 2000 \text { the government promoted } \\
\text { creation of university-owned enterprises and } \\
\text { granted them a series of tax preferences in } \\
\text { order to: } \\
\text { 1) attract additional financing to higher } \\
\text { education institutions } \\
\text { 2) utilize special knowledge of university } \\
\text { researches in industry through employment of } \\
\text { professors as experts for private companies } \\
\text { 3) accelerate development of applied research } \\
\text { via intensification of collaboration between } \\
\text { universities and industry } \\
\text { From } 2001 \text { on the basis of the decree of the } \\
\text { Ministry of Education of China the government } \\
\text { set the goal to change management structure of } \\
\text { enterprises in order to improve quality of their } \\
\text { operations }\end{array}$ \\
\hline Joint research centers & $\begin{array}{l}\text { Research centers founded by } \\
\text { Chinese universities, domestic } \\
\text { industrial enterprises and } \\
\text { multinational corporations }\end{array}$ & $\begin{array}{l}\text {-accelerated commercialization of domestic } \\
\text { technologies } \\
\text {-attraction of necessary financing to R\&D of } \\
\text { higher education institutions } \\
\text {-provision of jobs for university graduates } \\
\text {-acquisition of management skills by university } \\
\text { personnel } \\
\text {-adaptation of foreign and creation of own } \\
\text { domestic technologies }\end{array}$ \\
\hline $\begin{array}{l}\text { Independent universities } \\
\text { (colleges) }\end{array}$ & $\begin{array}{l}\text { Higher education institutions } \\
\text { founded by state universities } \\
\text { with attraction of financing } \\
\text { from private companies. } \\
\text { Independent universities } \\
\text { function on the basis of } 7 \\
\text { independencies }\end{array}$ & $\begin{array}{l}\text {-increase of population education level and } \\
\text { share of population with tertiary education } \\
\text { (long-term goal within a framework of } \\
\text { transition to the knowledge economy) } \\
\text {-development of vocational training programs } \\
\text { based on requirements and demands of } \\
\text { industrial enterprises } \\
\text {-creation of new professions, educational and } \\
\text { vocational programs in accordance with } \\
\text { requirements of private companies and } \\
\text { investors to graduates' skills and qualifications } \\
\text {-utilization of entrepreneurial skills of private } \\
\text { sector in management of independent colleges }\end{array}$ \\
\hline $\begin{array}{l}\text { 3) University-based } \\
\text { science parks } \\
\text { (technoparks) }\end{array}$ & $\begin{array}{l}\text { Physical place that supports } \\
\text { university-industry and } \\
\text { government collaboration } \\
\text { with the intent of creating } \\
\text { high technology economic } \\
\text { development and advancing } \\
\text { knowledge }\end{array}$ & $\begin{array}{l}\text {-accelerated commercialization of technologies } \\
\text { developed by universities through foundations } \\
\text { of start-ups aimed at technology } \\
\text { implementation } \\
\text {-technology transfer from universities to private } \\
\text { companies } \\
\text { - development of entrepreneurial skills of } \\
\text { university graduates } \\
\text {-job placement of students returning from } \\
\text { abroad } \\
\text {-attraction of venture capital with assistance } \\
\text { from foreign university graduates } \\
\text {-increase of investor attractiveness of territories } \\
\text { where science parks are located } \\
\text {-development of innovation infrastructure of } \\
\text { territories }\end{array}$ \\
\hline
\end{tabular}

PAGE 191| Journal of Corporate Governance, Insurance, and Risk Management | 2014, VOL. 1, Series. 1 
oday the government continues to strongly support the development of the knowledge economy. China's official "Report on the implementation of the central and local budgets for 2013 and the draft central and local budgets for 2014” indicates that expenditures on science and technology, expenditure on education, and expenditure on health care from the government budget continue to rise (Report on execution, 2014). Figure 1 illustrates the dynamics for the years 2012-2014.

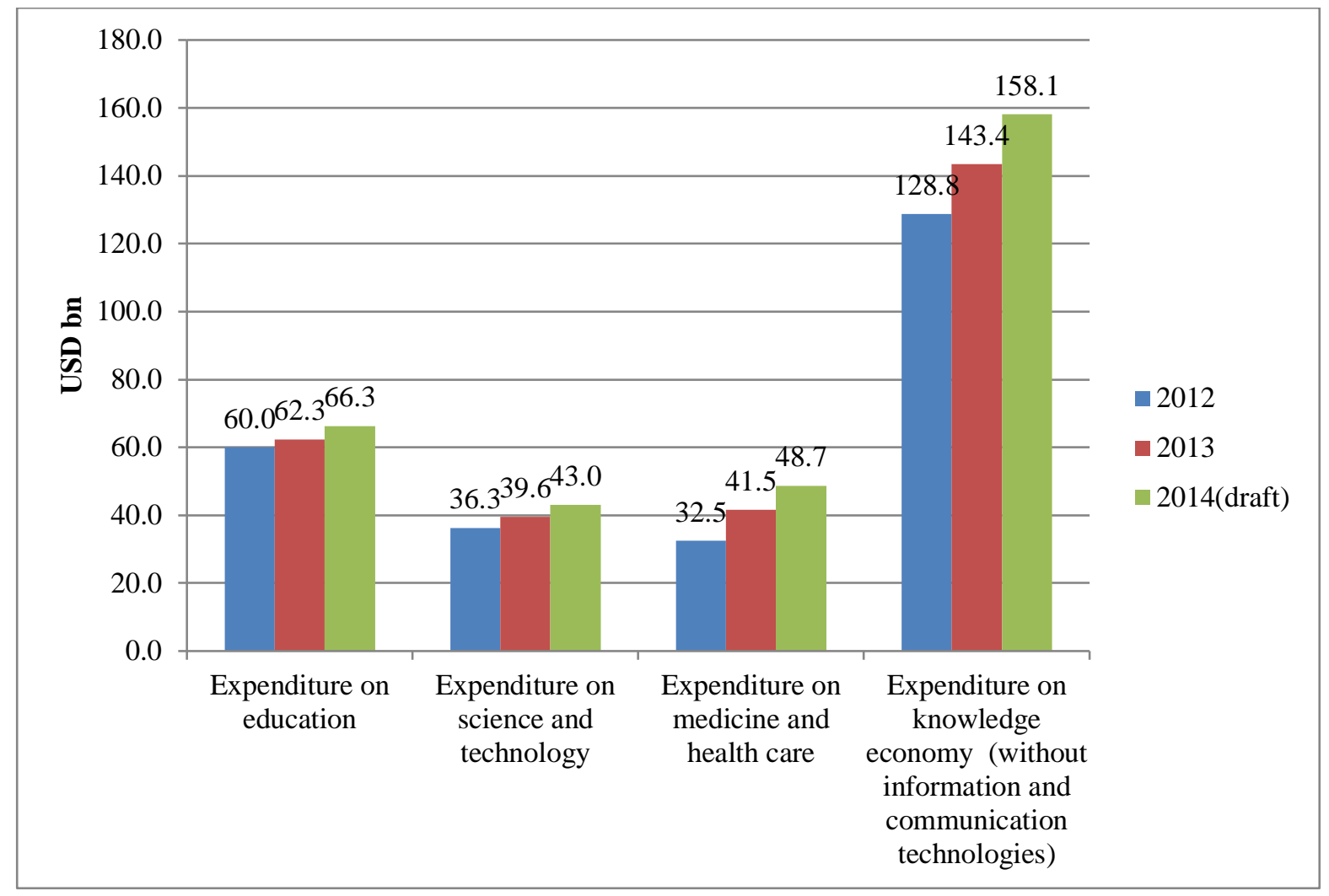

Figure 1: Expenditure on the knowledge economy from the budget in China, bn USD

Note: For the values for 2013 and 2014 an average exchange rate of CHY for the period January 1, 2013 to June 10, 2014 was used (1USD=6.23CNY); for the values for 2012 the official annual exchange rate was used $(1 \mathrm{USD}=6.31 \mathrm{CNY})$.

Here we use the extended definition of the knowledge economy and include health care as an additional pillar. Expenditure on the knowledge economy are sum of expenditure on education, science and technology, and health care and do not include expenditure on ICT.

Source: (Report on the execution, 2014).

In conclusion, we find strong support for Hypothesis 2. The government is directly involved in building the knowledge economy in China. It simultaneously targets the four knowledge economy pillars and successfully develops them. The involvement of government ranges from 
legislation acts (as in case of joint research centers) to direct financing of activities (e.g. university R\&D).

We now turn to Hypothesis 3 and will explore how public-private partnerships in innovation activities in the universities in China (Table 2) intensified the country's innovation activities in the past two decades. Each of the six types of partnership is discussed separately.

\section{Technology contracts}

Technology contracts are arrangements between a university and a private company and can take form of technology development (solution of a research task set by the company by the university employees), provision of technical services and technical consultancy. From six types of PPPs technology contracts are major source of financing with funds of the private companies going into research and development activities of the universities. The money is spent on enhancing research capabilities of the universities and development of applied science research. Technology contracts also act as a mechanism of tacit knowledge transfer from science to industry.

\section{Technology transfer and licensing}

Technology transfer mechanism as a form of PPP between universities and industry can take three district forms: transfer of patents, patent licensing, and non-patent technology transfer. From the point of view of realization of the government strategy of intensification of science and technology and progress towards the knowledge economy, the most important form of technology transfer was patenting of the scientific results. In the beginning of the 21 century the China lagged behind developed countries in licensing and patenting. In 2001 China had 1653 patents granted while Japan had 125704 patents and South Korea had 35900 patents granted (Xue, 2006). The government channeled financing into R\&D activities of the universities, and expenditure on R\&D in universities more than doubled from 2006 to 2010 (CNY 597.3 bn in 2010). The results were impressive. Today China has a reputation of major patent filer with 217000 patents granted in 2012. In 2010 the share of the universities in the total patents was 47\% (Rossiya i Strany Mira, 2012).

With the bulk of new technologies created within the university the technology transfer today functions as technology commercialization mechanism in China. The new technologies form 
basis of the China's technological platforms and lessen the country's dependence on the foreign technologies.

\section{University-owned enterprises}

University-owned enterprises or university-affiliated enterprises are a unique Chinese form of public-private partnership. There is no formal definition of a university-owned enterprise and the concept embraces all enterprises that are created and, in one way or another, controlled by universities.

The process of development of university-affiliated enterprises was divided into three stages. First stage covered a period from the 1980s to the 1990s. A distinctive feature of the first period was a spontaneous development of firms in the form of 1) joint commercial entities between universities and outside enterprises; 2) technology development companies created by universities and university departments; and 3) university-owned factories. In the UNESCO study (In Search of the Triple Helix, 2011) the spontaneous development is explained by the absence of a market to buy or sell technologies during the 1980s. University-affiliated enterprises acted as one of mechanisms for exchange and implementation of technologies. In 1989 sales of the university-owned enterprises in China reached CNY $470 \mathrm{mln}$ (Xue, 2006).

During the second stage (1991-2000) the government recognized the importance of the university-owned enterprises in the development of science and technology in China and promoted their establishment by giving them tax preferences. The government also created favorable working conditions for the university employees allowing them to simultaneously hold positions in the private firms and universities and participate in venture projects. Creation of the enabling environment resulted in the increase of the number of firms up to 5451 in 2000 with volume of sales reaching CNY 48.4 bn (Jin, 2013). By 2000 market for technologies was already in place in China and there was less need for the university-owned enterprises from the point of view of the government. During the period (2000-present) under pressure from the government some university-owned enterprises spun-off while others were forced to discontinue their existence. By 2009 the number of university-affiliated fell to 3643 but the volume of sales increased to CHY $141.2 \mathrm{bn}$.

\section{Joint research centers}


Emergence and proliferation of joint research centers as a form of PPP between universities and private companies are linked to the two official measures: Action Scheme for Invigorating Education in the $21^{\text {st }}$ century launched by the Ministry of Education in 1999 and the decree on the Rules of Patenting for SMEs (similar to Bayh-Dole Act of the USA). Joint research centers have been proliferating since the late 1990s with joint research centers with multinational corporations among them. In 2011 Tsinghua University had 40 international research centers (Tsinghua university, 2009).

Major contribution of the Chinese universities into these research alliances is talented and highly qualified research personnel. Through the collaboration with private companies universities develop new ideas and the personnel acquire management skills. Recent graduates have opportunities to further advance their knowledge and practical skills by interning for the private firms. Creation and commercialization of new technologies that take place within joint research centers further promote the knowledge economy.

We must note, however, that Chinese universities vary in their prestige, quality of educational programs, and the level of qualification of their faculty. So far the most prestigious universities have been involved in research collaboration (Zhejiang University, Shanghai Tong University, Tsinghua University, etc.). Provincial universities are involved to a lesser degree. In order to further advance towards the knowledge economy China needs to raise the level of education and research in provincial university including via establishment of joint research centers.

\section{Independent universities}

Independent universities or colleges ${ }^{2}$ represent another form of PPP that is unique for China. Independent colleges are financed by private companies but degrees are awarded by the state universities that act as parent institutions. Creation of first independent universities was initiated by institutions of higher education and not by any government legislation. City College of Zhejiang University in Hangzhou created in 1999 by a municipal government of Hangzhou, Zhejiang University, and Zhejiang Telecom Group, was the first independent college in China. Since 1999 the number of independent universities grew rapidly. In 2010 there were 323 independent universities in China (Baocun, 2012).

\footnotetext{
${ }^{2}$ Majority of independent universities offer only bachelor's degree programs and therefore are colleges according to the definition of higher education institutions in the US and Western Europe.

PAGE 195| Journal of Corporate Governance, Insurance, and Risk Management | 2014, VOL. 1, Series. 1
} 
From 1999 to 2002 independent colleges developed without any intervention from the government. After observing this process for a few years, at the end of 2002 the Ministry of Education officially approved the existence of independent universities that were defined as 'secondary undergraduate institutions, which are established according to new mechanisms and new models by state-owned colleges or universities' (Zhang and Adamson, 2011, p. 252).

The government viewed independent universities as a mechanism of improvement the overall education level in China and provision of additional places in tertiary education in response to the increased demand for education. The government planned to use independent universities to raise a share of population with tertiary education. An increase in the number of educational programs and institutions of higher education, including independent colleges, led to growth of the share of population aged 18-22 studying at universities from $12.5 \%$ in 2000 to 30\% in 2010 (China Statistical Yearbook, 2012).

Government established a focus of independent institutions: they had to concentrate on educational programs of a practical character (polytechnic), while state universities could continue to concentrate on educational program in fundamental sciences. It was assumed that the development of independent colleges would promote accumulation of practical knowledge by students and that this practical knowledge would comply with the requirements of potential employees and the level of technological progress in China. Finally, the government aimed at using entrepreneurial skills of the private sector in management of independent colleges.

Today the experience of creation of independent universities as a form of public-private partnership could be considered successful. Independent universities rarely face financial difficulties and the quality of education is considered to be high. Also, since businesses can influence curriculum of independent institutions and tailor it to needs and requirements of the modern production, they willingly hire graduates of independent universities.

\section{University science parks (technoparks)}

Process of creation of technoparks began in China during the last decade of the $20^{\text {th }}$ century. China's first university-based science park-Northeast University Science Park-was established in 1989 (Xue, 2006). The Chinese government was inspired by the success of Cambridge and Stanford science parks and played an active role in the process of creation of science parks. In 2000 a national certification program of university-based science parks began. 
In 2010 there were 86 university-based science parks in China with 4346 companies established on the premises of science parks (in 2002 there were 720 such companies) (Jin, 2013).

A model of a university-based science park in China and its main goals generally repeated the agenda of the Western science parks. Among the goals were: company spin-offs; collaboration between universities and private companies; and commercialization of research results at local and international markets. However, Chinese technoparks also possess a unique countryspecific feature in relation to the knowledge economy. Science parks became places of employment for the students returning from abroad. Many highly qualified scientists with doctoral degrees in basic and applied sciences from Western universities and high potential for new knowledge generation founded high-tech companies in science parks. Recognizing the potential of the returning graduates the government monitors the process of attraction of foreign-university graduates to science parks (Van Essen, 2007).

During the past decade the Chinese university-based science parks received various grants from the government and participated in a series of innovation projects. Despite the fact that some science parks failed to develop in accordance with the government of objectives, others (with Zhongcuancun Science Park among them) became growth poles for the accelerated innovative development of the territories.

Based on the study of the six private public partnerships in innovation activities of the universities in China we find support for Hypothesis 3 and confirm that PPPs has played an important role in the creation of the knowledge economy in China.

\section{CONCLUSION}

The study explored China's progress towards the knowledge economy with an emphasis on education and innovation pillars. According to the international rankings that reflect countries' progress towards the knowledge-based society - Knowledge Economy Index, Global Competitiveness Index and Human Development Index - advancement of China is evident. In 2012 China was placed higher than its BRICs partners (Russia, India, and Brazil) in the Global Competitiveness Index ranking.

The government has played the leading role in the creation of the knowledge economy over the past 20 years and continues to do so today. With its new economic model 'Made and Created in China' that replaced the old 'Made in China' model the government has enacted new PAGE 197| Journal of Corporate Governance, Insurance, and Risk Management | 2014, VOL. 1, Series. 1 
legislation in science and education sectors, intensified R\&D activities, technology transfer and commercialization, and initiated reforms of the education sector aiming at greater share of people with tertiary education. In 2013 total expenditure on education and science accounted for $4.46 \%$ of the total budgetary expenditure and further growth of the share to $5.1 \%$ is projected for $2014^{3}$.

Public-private partnerships positively impacted the construction of the China's knowledge economy. While some of PPPs mechanisms contributed to innovation development during some period of time (as in case of university-owned enterprises functioning as technology transfer mechanisms up to 2000) others had a long lasting effect (i.e. increase in tertiary enrolment through independent universities).

However, several problems with regard to the creation of knowledge economy remain and should be addressed. Of particular importance is an uneven development of the country with the capital and large cities having advanced much more than provincial towns and rural settlements. This calls for special attention from the government. Development and financial support of provincial universities can lay foundation for rising average education level which still remains low in comparison to the developed countries.

The study has important policy implications. First, China's experience demonstrates that government has to lead the reforms of science and education sector to further advance towards the knowledge economy. Second, other countries, including Russia, can seriously consider adapting public-private partnership mechanisms to develop innovation activities of the universities. In their future work the authors plan to explore how some of the country specific public-private partnerships can be implemented in Russia.

\section{Acknowledgement}

This paper was prepared within the framework of the program of the Presidium of the Russian Academy of Sciences No. 35 “Economics and sociology of science and education”.

\section{REFERENCES}

Bai, C. (2011), “An overview of S\&T innovations in China”, paper presented at the 4th

\footnotetext{
${ }^{3}$ Authors' calculations based on (Report on execution, 2014).

PAGE 198| Journal of Corporate Governance, Insurance, and Risk Management | 2014, VOL. 1, Series. 1
} 
Innovation Conference, 8 August, Sao Paolo, Brazil, available at: http://www.inovacaonaindustria.com.br/portal/wp-content/uploads/2011/08/An-Overviewof-ST-and-Innovation-in-China_BAIChunli.pdf (accessed 11 June 2014).

Baocun, L. (2012), “Independent colleges in China: an innovation or freak”, paper presented at the 56th Annual Conference of the Comparative and International Education Society, 22 April, San Juan, Puerto Rico, available at: http://citation.allacademic.com/meta/p556423_index.html (accessed 11 June 2014).

China Statistical Yearbook 2011 (2012), National Bureau of Statistics of China, Beijing.

Chen, D. and Dahlman, C. (2005), “The knowledge economy, the KAM methodology and World Bank operations”, working paper, The World Bank, Washington DC, 19 October.

Dalhman, C. and Aubert, J.-E. (2001), China and the Knowledge Economy: Seizing the $21^{\text {st }}$ Centrury, World Bank Publication, Washington DC.

Dunning, J.D. (ed) (2000), Regions, Globalization, and the Knowledge-Based Economy, Oxford University Press, New York.

Human Development Report 1998 (1998). Oxford University Press, New York.

Human Development Report 2013. The Rise of the South: Human Progress in the Diverse World (2013), UNDP, New York.

Jaffe, A. and Trajtenberg, M. (2002), Patents, Citations, and Innovations. A Window on the Knowledge Economy, MIT Press, Cambridge, Massachusetts.

Jin, H. (2013), "Entrepreneurial universities and industrial creation in China”, working paper № 166, Hitotsubashi University, Tokyo, March.

Kaneva, M. (2014), “Gosudarstvenno-chastnoe partnerstvo v innovatsionnoj deyatel'nosti vuzov Kitaya” [Public-private partnership in innovation activities in the Chinese higher education institutions], Vestnik Novosibirskogo Gosudarstvennogo Universiteta. Seriya: Sotsial'no-ehkonomicheskie Nauki [Herald of Novosibirsk State University. Social and Economic Sciences Series], Vol. 14, Issue 1, pp. 69-80 (in Russian).

Kaneva, M. and Untura, G. (2014), "Public-private partnership in innovation activities of the universities in China” in Economic and social development: 6th International scientific conference of economic and social development and 3rd Eastern European ESD conference: business continuity (Vienna, 24-25 April 2014): book of proceedings [Electronic resource], VADEA, Varazdin, pp. 594-604.

Kochetkov, G.B. (2013), “SSHA: novaya rol' universitetov v innovatsionnom razvitii” [The 
United States: new role of university in innovation development], in Milner, B. Z, (Ed), EHkonomika Intellektual'nye Resursy, Upravlenie Znaniyami [Economics of Intellectual Resources: Knowledge Management], Infra, Moscow, pp. 405-423 (in Russian).

Kuleshov, V.V., Untura, G.A., Evseenko A.V. (2012), "Nauka, obrazovanie, innovatsionnye tsentry: regional'nye aspekty integratsii” [Science, education, and innovation centers: aspects of integration], EHKO [EKO], No. 9, pp. 95-114 (in Russian).

Li, T. (2003), In Search of Reforms' Directions and Open Policy, Volume 2, Social Science Documentation Publishing House, Moscow.

Li, T. (ed) (2010a), Tieying Reforming China: Major Events (1978-1991), Volume 3, Enrich Professional Publishing, Hong Kong.

Li, T. (ed) (2010b), Tieying Reforming China: Major Events (1992-2004), Volume 4, Enrich Professional Publishing, Hong Kong.

Martin, M. (ed) (2011), In Search of the Triple Helix. Academia-Industry-Government Interaction in China, Poland, and the Republic of Korea, UNESCO, Paris.

Park, S.-C. (2012), “Competitiveness of East Asia science cities: discourse on their status as global or local innovative clusters”, AI \& Society, Vol. 27, Issue 4, pp. 451-464.

Porter, M. and Schwab, K. (ed) (2008), The Global Competitiveness Report 2008-2009, World Economic Forum, Geneva.

The Knowledge-Based Economy (1996), OECD, Paris.

Ramesh, S. (2013), “China’s transition to knowledge economy”, Journal of Technology Transfer, Vol. 4, Issue 3, pp. 473-491.

Report on the execution of the central and local budgets for 2013 and the draft central and local budgets for 2014 (2014), available at http://russian.news.cn/china/201403/15/c_133188856.htm, March 15 (accessed 11 June 2014)

Rossiya i Strany Mira [Russia and Countries of the World]: Statistical Yearbook 2012 (2012), Rosstat, Moscow (in Russian).

Sala-i-Martin, X. (ed) (2003), Global Competitiveness Report 2003-2004, World Economic Forum, Geneva.

Saisana, M. and Munda, G. (2008), “Knowledge Economy: Measures and Drivers. Joint Research Commission Scientific and Technical Reports, The European Commission, European Communities, Luxembourg.

School enrolment, tertiary (\% gross) (2014), available at: 
http://data.worldbank.org/indicator/SE.TER.ENRR last updated January 2014 (accessed 11 June 2014).

Schwab, K. (ed) (2012), The Global Competitiveness Report 2012-2013, World Economic Forum, Geneva.

Smith, K. (2002), “What is the 'knowledge economy'? Knowledge intensity and distributed knowledge bases”, discussion paper No. 2002-06, Institute for New Technologies, the United Nations University, Maastricht, June.

Teece, D. (1998), “Capturing value from knowledge assets: the new economy, markets for know-how, and intangible assets, California Management Review, Vol. 40 No. 3, pp. 55-82.

Tao, R. (2005), "Probing the emergence and development of independent institutions"

(Master thesis), Nanjing Normal University, Nanjing.

The knowledge economy index, available at:

http:// http://info.worldbank.org/etools/kam2/KAM_page5.asp, last updated January 2012 (accessed 11 June 2014).

Tsinhua university. (2009), available at http://is.tsinghua.edu.cn/EN/general/tsinghua.html (accessed 11 June 2014).

Untura, G.A. and Evseenko, A.V. (ed) (2011), Innovatsionnyj Vektor Ehkonomiki Znaniya [Innovation Vector of the Knowledge Economy], SB RAS Publishing, Novosibirsk (in Russian).

Untura, G.A. (2009), “Ehkonomika znanij v Kitae i Rossii: problemy i perspektivy” [The knowledge economy in China and Russia: problems and perspectives”, Prostranstvennaya Ehkonomika [Spatial Economy], Vol. 4, pp. 88-105 (in Russian).

Untura, G.A. (2013), "World tendencies of education and regional experience of NSU: from basic researches to innovations” Applied and fundamental studies : proceedings of the 2nd International Academic Conference, March 8-10, 2013, St. Louis, Missouri, USA / ed. by Y. Maximov, Science and Innovation Center Publishing House, St. Louis, Vol. 2., pp. 217225.

Van Essen, C. (2007), “The development and diversity of science parks in China: three cases” (Master thesis), Erasmus University, Rotterdam.

Wang, H. and Zhou, Y. (2009), “University-owned enterprises as entry point to knowledge economy in China”, Science and Public Policy, Vol. 36 No. 2, pp. 103-108.

Wu, W. (2010), “Higher education innovation in China”, available at 
http://siteresources.worldbank.org/INTEASTASIAPACIFIC/Resources/China-

HigherEducationInnovation.pdf (accessed 12 June 2014).

Xue, L. (2006), “Universities in China’s national innovation system”, paper presented at UNESCO Forum on Higher Education, Research and Knowledge, November 27-30, Paris, France, available at: http://portal.unesco.org/education/es/files/51614/11634233445XueLan-EN.pdf/XueLanEN.pdf (accessed 11 June 2014).

Yee, L. (2011), “China tops U.S., Japan to become top patent filer”, available at http://www.reuters.com/article/2011/12/21/us-china-patents-idUSTRE7BK0LQ20111221 (accessed 11 June 2014).

Zhang, L. and Adamson, B. (2011), “The new independent higher institutions in China: dilemmas and challenges”, Higher education quarterly, Vol. 65 No. 3, pp. 251-266. 